posed in Section VIII of this Report, to be added to the present national park, contains the greatest possible number of rhinoceros in their natural habitat. At the same time it is almost entirely free from human occupation and consequently there would be a minimum of administrative work.

\title{
III. History of the Area
}

The present rhinoceros areas of Nepal, in fact the whole of that country, have been up till recent times a closed book to foreigners. Visits by outsiders were discouraged, even forbidden. Perhaps the first foreigner to tour in the Nawalpur, Chitawan, and Reu Valley areas was Mr. E. A. Smythies, who during World War II, was Forest Adviser to the Nepal Government. In the course of his duties Smythies visited almost all the submontane tracts along the $\mathbf{5 0 0}$ mile sal belts of the Nepal terai.

There is some historical evidence that the Rapti Valley, as Chitawan is usually known, was once much more thickly populated than at the beginning of this century, and it is possible that malaria was the chief reason for any subsequent depopulation of the area.

The Rapti Valley has remained closed even to most prospective Nepali settlers, not only because of malaria, but because it was strictly protected as the special shooting preserve of the rulers of Nepal, whose huge camps and elephant beats were known the world over. Up till recent years almost the only people living in the area were simple "Plains Nepalis"-the Tharus, who appear to have become immune to malaria and who incidentally provide practically all the elephant drivers of that country. These people also provided the labour required for making rough cross-country tracks in the dry cold-weather months and for preparing shooting camps.

A special department of armed men has existed for many years to protect the rhinoceros, tiger, and other game. At the time of my visit it consisted of : 1 Commander (Captain), 1 Assistant (Lieutenant), 4 Subedars, 24 Havildars, and 122 Rhino Guards.

Mr. E. A. Smythies in his book, Big Game Shooting in Nepal (1942), and his wife Olive, in her Tiger Lady (1953) speak in glowing terms of their trips to the Narayani, Rapti, and Reu valleys in the years 1941-1945. They found that, whereas in the rest of the Nepal terai there was practically no game left, here was still a sportsman's paradise, with uncounted numbers of rhinoceros and other big game, and comparatively unspoiled habitat. 
In 1951 as a result of the political upheaval in which the Rana regime came to an end and democracy came into being, the area underwent a change. Poaching increased to an alarming extent-in fact this seems to have been the peak year for illegal slaughter of rhinoceros.

From 1951 onwards the weakening of protection in the big game reserve meant that malaria was now the main, if not the sole, deterrent to settlers coming from the hills into the Rapti Valley. It was not possible in such a mountainous country as Nepal to prohibit indefinitely the influx of human settlers into grasslands suitable for cultivation of crops. "Hills Nepalis," Gurungs, Magars and others, started to come down into the Rapti Valley unofficially; and officially the Rapti Valley Multi-Purpose Development Project began in 1955 to settle cultivators from the hills in the western portion of Chitawan south of Narayangarh, at the rate of 2,500 persons a year. By March, 1959, 12,000 persons had been settled on grasslands once occupied only by rhinoceros and other species of wild life, and $52 \frac{1}{2}$ square miles had been thus opened up and developed. It is proposed to settle a further 25,000 persons in the Rapti Valley in the near future.

A new gravelled road from Hitaura to Bharatpur and Narayangarh has been constructed jointly by the United States Operations Mission and the Nepal Government, and this was completed by March, 1959, except for a bridge and the big causeway near Hitaura. It was claimed that recent malaria control measures had succeeded in making the valley considerably safer for human occupation.

Besides the 12,000 persons officially settled by the R.V.M.P. Development Project, a large unspecified number of people from the hills have settled unofficially in various parts of the Rapti Valley during the last few years. It is obvious that if the influx of human settlers continues unchecked wild life will ultimately disappear from this renowned place.

The Nepal Government has been aware of this danger, and during the winter of 1957-58 steps were taken to allot a part of the north of the valley as a national park. In January, 1959, the Mahendra Mriga Kunja (Mahendra Deer Park), or Mahendra National Park, of 68 square miles was formally opened by King Mahendra. It is proposed that a "Wild Life Sanctuary" (possibly for 10 years only, after which it may revert to shooting blocks) shall be created south of the national park to include most of the rhinoceros area as well as cultivation and grazing 


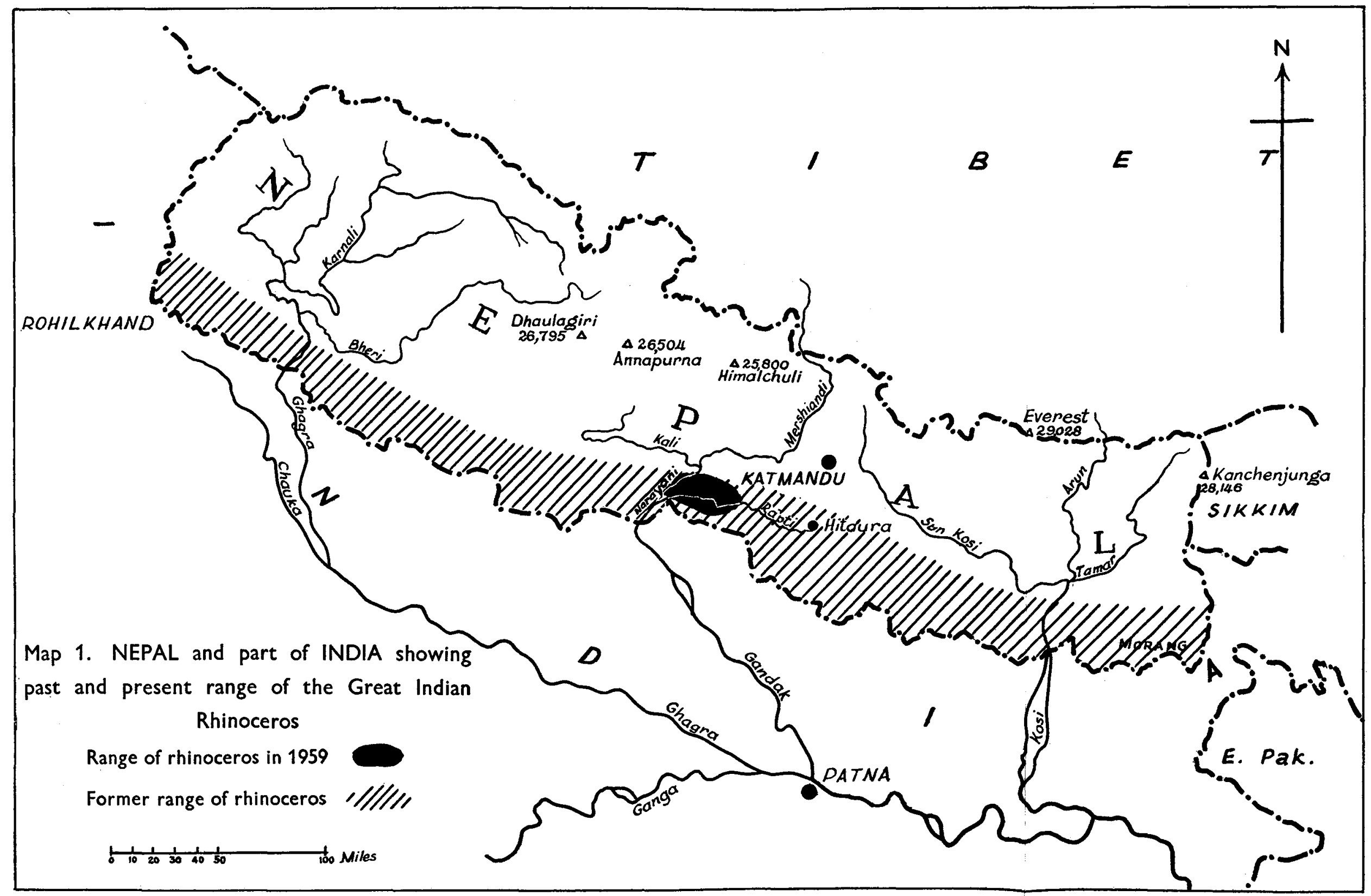

Facing p. 62 
areas. Another area has been allotted as " King's Reserve" and another as "Shooting Blocks" (see map No. 2).

\section{Geograpiticai and Ecological}

The present rhinoceros area comprising the valleys of the rivers Naranyi, its tributary the Rapti, and the Rapti's tributary the Reu, is often loosely spoken of as part of the Nepal terai. Terai in northern India and Nepal is, strictly speaking, moist country a few miles from the base of the Himalayas, below the bhabar, which is dry country with a subsoil of boulders right at the foot of the Himalayas. Chitawan, or the Rapti Valley, is a dun-a plateau or flat valley inside the foothills of the Himalayas ; its altitude is between 900 and 1,000 feet above sea level, and it has most of the typical vegetation of the terai which is usually at 350 to 600 feet.

The dun of the Rapti Valley is approximately 40 miles long from east to west, and varies from 4 miles wide at Ramoli at the eastern end, to about 16 miles at its widest, in the west near the Narayani river. This is the main rhinoceros area, bounded on the north by range upon range of the Mahabharat (Himalayas) and on the south by the Churia Range (Siwaliks). Another area with similar vegetation lies west of the Narayani River and down the bank of that as far west as Tamashpur. A third area is the Reu Valley which is divided from the Rapti Valley by a ridge of the Churia Range. The scenery, climate and vegetation of the Rapti dun is very similar to that of the beautiful Corbett National Park of Uttar Pradesh in India.

Records of rainfall for this area are scanty, and have only been kept during the past three years. It appears that 65-70 inches, falling mainly between June and September, is the normal rainfall of Bharatpur at the western end of Chitawan.

The terrain of these three valleys can be conveniently divided into riverain, grassland, and timber forest.

1. Riverain, comprising all the low-lying strips along the river beds as well as the islands in the river beds.

2. Grassland, above flood level, most of which is either being or is about to be occupied, cultivated and grazed by human settlers.

3. Timber forest, mainly on the higher undulating portions of the dun, and covering most of the hills of the area.

Riverain.

The Narayani (or Gandak) is a huge river, and occasionally washes a live rhinoceros down into India. In this area it widens 